\title{
SECOND LANGUAGE TEACHING STRATEGIES WITHIN THE FRAMEWORK OF INDIVIDUALISATION AND DIFFERENTIATION IN HIGHER EDUCATIONAL INSTITUTIONS
}

\author{
Oleksandr Lahodynskyi ${ }^{1}$, Inna Semeniako ${ }^{2}$ \\ Military Diplomatic Academy named after Yevheniy Bereznyak, Kyiv, Ukraine \\ Phone: ${ }^{1}+380999551959,{ }^{2}+380679143186$ E-Mail: ${ }^{1}$ berezan2016@meta.ua, ${ }^{2}$ isemeniako@ gmail.com
}

\begin{abstract}
The article deals with the issue of second language (SL) teaching in the higher educational institutions. The achievement of SL training goals by students is closely connected with the implementation of teaching and learning techniques based on concepts of individualisation and differentiation in higher education. Having analysed the concepts mentioned above, the authors define their role within the framework of SL training of the future specialists and, on this basis, outline SL teaching strategies that can be applied both during classroom and self-study work. They are defined as general mechanisms for the most effective planning, organisation and implementation of SL teaching based on students' psychological peculiarities. They are aimed at creating the best and most comfortable conditions for the student's SL learning and developing new ways of mastering a SL. They increase students' motivation and maintain interest to learn $S L$ when certain organisational conditions are observed and the offered exercises correspond to the students' temperaments, personality types, and learning styles.
\end{abstract}

Key words: individualisation, differentiation, SL teaching strategies, temperaments, personality types, learning styles, higher educational institutions

\section{INTRODUCTION}

Current foreign policy priorities of Ukraine, its ambitions to join the European Union and NATO require that the Ukrainian specialists should be not only of a high level of professionals in their trade, but also have excellent SL speaking skills sufficient for working hand-in-glove with partners from oversees. Thus, Ukraine needs a well-organised and scientifically supported system of SL training in the higher educational institutions. Such system should be based on the pedagogical principles of individualisation and differentiation, which is a key for the development of creative personalities of modern Ukrainian specialists with higher education. Such specialists should be able to accomplish effectively professional tasks under challenging conditions of today's turbulent world in close conjunction with their foreign counterparts. With this purpose in mind, we seek to establish such a SL training system in the higher educational institutions that would include not purely a linguistic aspect, but also consider individual psychological features of students when acquiring higher education. 


\section{LITERATURE REVIEW}

In overall, individualisation and differentiation of professional training are applied in different types of educational institutions, for different categories of students all over the world. This issue holds an important place in scientific research of many scholars. Let us have a closer look at their works.

Muntyan (2013) has explored adaptive ways and conditions to provide individualised training of students in teaching foreign languages for specific purposes. According to her, regular implementation of public presentation held in a foreign language is an effective means of individualisation of professional teaching.

García (2013) has studied some aspects of language learning autonomy which include the relationships between learning styles of university students and different reading and navigational modes they use when faced by tasks requiring effective management of webbased information. In her doctoral dissertation the author has offered learning strategies that can help students to develop their reading modes in different genres of digital media, i.e. cybergenres.

Kononenko (2015) puts forward a worldview approach to the summary of types of learning and their application based on C. Graves's Theory of Emergent Cyclical Levels of Existence. Some aspects of this work can be useful for elaborating ESP teaching strategies for individuals with different worldviews.

Doronkina and Ivasiuk (2015) outline the peculiarities of using the "multiple intelligences" theory in foreign languages training at technical universities. In their research, the authors describe the peculiarities of each type of intelligence, as well as analyse the methods and means of teaching foreign languages in accordance with them.

Kubacheva and Baeva (2017) explore the problem of considering extroverts' and introverts' individual and mental features in foreign languages teaching at nonlinguistic high schools. The authors prove that teaching efficiency depends not only on the individual training approaches, but also on students' cognitive abilities, which affect the process of perception and assimilation of training material.

Although the problem of individualisation and differentiation in SL training holds an important place in scientific researches, it cannot be considered completely solved. Taking into account the high priority tasks and the significance of the future specialists' abilities to be linguistically prepared to perform them, often in high risk environment, SL training in the higher educational institutions needs additional research.

As it can be observed, the suggested teaching techniques do not address in full scale the SL training objectives in the higher educational institutions. Neither do they meet the future specialists' professional requirements and psychological demands of their working environment. Thus, the aim of this paper is to outline the SL teaching strategies in the higher educational institutions in the context of individualisation and differentiation to satisfy the linguistic and professional needs of the future specialists.

\section{THEORETICAL ANALYSIS OF THE PROBLEM}

Having a global look at the problem, we can observe the following. In the USA individualisation and differentiation include all forms and methods aimed at taking into account individual psychological characteristics of students during their training. They cover all training strategy. In French pedagogy, individualisation is targeted at improving students' self-studies work according to their individual abilities. 
Most scholars have different approaches to defining individualisation: simultaneously it is defined as a way, method and principle of training (Kitajgorodskaja, 1986; Zimovina, 2001; Muntyan, 2013). In some works, the terms "individualisation" and "differentiation" are considered identical (Kruteckij, 1986; Zimovina, 2001, p. 82 - 83). However, the analysis of special research works made it possible to claim that it is not so (Bulygina, 1999, p. 48 - 57; Zimovina, 2001, p. 83 - 98). As follows, individualization consists in considering students' individual characteristics and abilities in all forms and methods during training process being carried out according to the same curriculum within the same training group. While differentiation is considered to be a form of individualisation, which envisages grouping of students based on their individual psychological characteristics or series of characteristics. In this case students are trained in separate groups and according to individual training programmes.

As the above mentioned definitions suggest, these terms are closely connected with the concept of individuality, which is, following Leont'ev (2007), "a reflection of the uniqueness of the personality together with a specific way of his/her individual's, personal and subjective manifestations" (p. 19). Being unique and inimitable, each person manifests oneself in one's own way in various activities, including training. Therefore, it should be accepted that the SLP training in the higher educational institutions is based on the mixed individual and differentiated approach which can be observed in the following two ways: the division of students into groups is based on their individual psychological characteristics; individual psychological characteristics are taken into account while SL methods of teaching are applied.

In this way, individualisation and differentiation in SL training of the future specialists can be defined as the principles of teaching and learning which enable to create optimal conditions for the students' learning SL to satisfy their professional needs considering their individual psychological characteristics; adopt new comfortable individual ways of constantly improving their SL levels; develop an active, and creative personality of a future specialist able to work in today's high-risk environment in liaison with foreign language speaking partners.

\section{SL TEAChING STRATEGiES}

Individualisation and differentiation of SL training presume considering students' individual psychological characteristics, namely during class work and extracurricular work of both teaching staff and students. Within this framework, SL teaching strategies can be defined as general mechanisms for the most effective planning, organisation and implementation of SL teaching based on students' psychological peculiarities. This is aimed at creating the best and most comfortable conditions for the students' SL learning and developing new ways of mastering a SL.

In the first turn, SL teaching strategies should increase the students' motivation to learn the language. This means the organisation of the learning environment which will facilitate enhancing students' motives for SL learning. The motives are aimed at succeeding in acquiring the SL when the following conditions are observed:

- creation of favourable atmosphere in the classroom and during extracurricular work of the students (reward for successfully completed tasks; direction to succeeding in task completion and avoiding troubles and difficulties; making corrections without 
interrupting the communication process; providing conditions for an equal person-toperson interaction between the teacher and students);

- offering original communicative tasks that involve thinking and allow the students to discover something previously unknown by using their own personal reserves;

- involvement of the students' various skills, not only communicative but also other types of activities, as well as their personal experience to reinforce basic psychological conditions associated primarily with personal feelings concerning the importance of work and its results necessary for meeting future professional challenges;

- allowing the students to complete some challenging tasks independently to demonstrate their creativity and ingenuity;

- enabling students to see and feel the results of their work by providing a continuous feedback;

- considering the congruence of task complexity with students' abilities to complete it, as well as the congruence of its level of complexity with encouragement from teacher's side (Klimchuk, 2006, p. 20; Nikolic \& Cabaj, 2000, p. 197 - 202).

So, in this case, the SL teaching strategies are aimed at enhancing students' motivation and, above all, should arouse and maintain interest to learn a SL. It is also important to consider various temperaments during the SL training. Therefore, the SL teaching strategies should be aimed at comfortable work with every type. Thus, working with the sanguine students, the SL teaching strategies should be focused on:

- developing their abilities to focus and concentrate on some details to remember oral or written foreign language information;

- alternating between different types of exercises changing the nature of activities, preventing monotony and uniformity of work within the classroom;

- involving students into active exercises and collective interaction in order to facilitate expressing their emotions;

- developing the students' integrity to complete the exercise being started;

- taking control of students' participation in a group work, namely their relationships in order to prevent some of them from falling under the influence of others.

Working with the choleric students, the SL teaching strategies should be focused on:

- containing the students' reaction in case of sudden changes of mood; maintaining a calm, normal communication;

- containing the students' impulses to start and complete the task quickly; providing them with detailed, repeated instructions;

- making the students think over their answers more thoroughly; working at tasks that contribute to the development of language and speech tools;

- involving the students in active exercises (role-plays, discussions, debates) which exceed the level of their speaking skills to some degree, but maintain interest to SL learning;

- taking control of the students' participation in a group work to prevent misunderstandings and conflicts.

Working with the phlegmatic students, the SL teaching strategies should be focused on:

- providing the students with additional time to complete the tasks;

- stimulating and encouraging any initiative from their side; 
- gradual alternating between quiet individual tasks and more active competitive group exercises (in this case it is advisable to assist the students in preliminary training of their lexical and speaking skills);

- taking control of the students' participation in group work to prevent the suppression of their initiative and activity.

Working with the melancholic students, the SL strategies should be focused on:

- maintaining a positive atmosphere in the classroom and constant encouraging of speaking activities;

- providing favourable organisational and pedagogical conditions by establishing trustful contacts and preliminary preparation for more active participation of the students in exercises that involve collective interaction;

- offering new exercises only in case of preliminary preparation and providing necessary environment for their completion;

- taking control of the students' participation in a group work to prevent misunderstandings within the group and the suppression of their initiative and activity.

Taking into account that there are no pure temperaments, it is advisable for a teacher to combine the mentioned above strategies in SL training. Within this framework one more component should be noted - a type of personality. Depending on students' being extroverts or introverts, different SL teaching strategies should be applied.

Therefore, working with extroverts the SL teaching strategies should be aimed at:

- offering more active tasks (discussions, debates, role-plays, etc.);

- giving possibility to communicate and discuss results when written assignments are being done;

- focusing more on logical writing (making plan, discussion of its points, etc.).

When working with introverts, the SL teaching strategies should be directed at:

- offering individual written assignments with preliminary preparation;

- creating favourable conditions for gradual involvement of the students into oral group work with further gradual change of usual conditions of communication;

- being ready for students' making frequent alterations in written assignments.

By applying these strategies, the teacher should take into account the students' need to form susceptibility to oral collective interaction, due to the nature of their future professional tasks. Thus, within SL training process, the students should be directed to extraversion. We have outlined SL teaching strategies based on different learning styles. These strategies provide optimal conditions for SL teaching when the peculiarities of each type are observed (Reid, 1995, p.199; Byrnes, 2013, p 16 - 18).

Therefore, working with visuals, the following strategies should be considered:

- such students should take central seats in the class-room, located further from windows and doors; they also should be able to work on their own, namely read aloud or whisper words;

- students should be taught to write down verbal instructions to exercises and read them out for better understanding and memorising, as well as thinking the task over and imagining the environment for task completion;

- regular written assignments should be offered, aimed at reinforcing the language material (making sentences and texts with active vocabulary; taking notes of important points while completing listening or reading tasks and, if possible, highlighting these aspects with different colours); 
- assignments should be offered that involve mind mapping, different types of graphics etc. in order to teach students to write down foreign language information quickly;

- exercises for practicing listening and speaking skills should be based on video clips to enable the students to perceive the speakers visually;

- pre-reading tasks should be carefully selected and include exercises that allow the students to preview the text, focusing on its specific details, parts, graphics, etc;

- exercises should be offered that involve frequent use of cards with new words and expressions written in different colours on one side with their translation or definition on the other side to enable the students to memorise new vocabulary better (in this case, the memorized vocabulary should be written down).

Working with audials, the SL teaching strategies should include such measures:

- focus on working in pairs (this includes students' reading information aloud, practicing their speaking skills in order to solve some problematic issues);

- always give the instructions for assignments verbally, even if they are written; if it is necessary, give detailed explanations; recommend the students to review the objectives and instructions to the exercises before doing them;

- focus on oral tasks, teach the students to speak out learnt words and expressions, retell texts;

- think about pre-reading tasks which would enable the students to discuss the text with the teacher or other students in advance;

- use cards with new words and expressions written in different colours on one side with their translation or definition on the other side to enable the students to memorise new vocabulary better (in this case, the memorised vocabulary should be spoken out);

Working with kinesthetic types of the students, the teacher should focus on the following SL teaching strategies:

- the students should take comfortable seats in the class-room (they can teeter on chairs or push their feet off the floor, squeeze objects with hands, etc., but in any case, without distracting other students or the teacher from work); during self-study such students should not take their traditional seats;

- oral exercises should involve role-plays and enable such students to move, touch objects, model objects etc. when the task is being performed;

- written assignments must involve filling in the gaps with answers chosen by the students on their own;

- vocabulary learning tasks must be accompanied by constant movement or change of position in the classroom;

- pre-reading tasks should include exercises that would enable the students to look through the key words, expressions, graphic images in advance and enable them to read "from the end to the beginning";

- before undertaking written tasks, the students should have time and opportunity to think the topic over, make graphic marks and draw images in the draft.

If the same characteristics of each learning style are available within the group, it is advisable to combine the above mentioned strategies. Such approach will encourage the students to master SL better. 


\section{CONCLUSION}

Individualisation and differentiation in SL learning and teaching both relate to the concept of students' individuality. They enable favourable conditions for students' SL learning to meet their professional needs. They also contribute to developing active and creative personalities of future specialists who are able to constantly improve their SL proficiency level. Within the framework of individualisation and differentiation, we have developed SL teaching strategies aimed at the most effective planning, organisation and implementation of SL mastering based on students' psychological peculiarities.

Among these peculiarities, motivation to learn the language plays a very important part. To increase the students' motives to learn SL, the teaching strategies envisage creation of a 'kind' class-room environment, interesting learning materials and involving a variety of students' skills in the learning process including personal experience, offering students tasks requiring problem-solving; providing a continuous feedback to them; considering such important factor as difficulty of exercises offered to the students.

Besides, various temperaments of students should also be considered in the language teaching process. Here, the teaching strategies offer different approaches to planning and organisation of SL learning in the class-room with sanguine, choleric, phlegmatic, and melancholic types. It is important for the teacher to be able to combine the above mentioned strategies as the majority of students are characterized by mixed temperaments.

SL teaching strategies also vary according to students' personality types. Students identified as extroverted should be offered interactive exercises. They should be allowed to discuss their written tasks with the teacher or other students. Before doing some written exercises, teachers should suggest extroverts making logical plans of their essays. Working with introverted students the language teaching strategies should be directed at offering them individual written assignments with preliminary preparation. They enable gradual involvement of the students into more active speaking activities. Teachers also should get used to students' making frequent alterations in written assignments.

Language teaching strategies, based on various learning styles, envisage different activities for visual, audial, and kinesthetic students. Working with visuals the teacher should ensure that such students learn better when they get graphical information. The 'audials' should get more opportunities to receive learning material verbally, while 'kinesthetic' types are comfortable with SL learning when constantly moving and changing positions.

The SL teaching strategies are not the rules but recommendations to the teachers on how better to organise the SL process in the higher educational institutions. They cannot solve all the problems and require additional research on how to implement them within the class-rooms of students with different degrees of peculiarities.

\section{REFERENCES}

Byrnes F. (2013). Toolkit for Accelerated Learning. Ottawa: Canadian Forces Language School.

García, C. G. (2013) Learning styles and reading modes in the development of language learning autonomy through 'cybertasks'. Unpublished doctoral dissertation. Castellón, Spain. Retrieved November 9 2017, from TDX (Theses and Dissertations Online) website, http://hdl.handle.net/10803/125440 
Doronkina, N. E., Ivasiuk, O. V. (2015). Students' individual characteristics and their consideration in teaching foreign languages. Advanced Education, 4, 18-21. Retrieved November 11 2017, from Advanced Education website, http://ae.fl.kpi.ua/article/ view/57041

Kononenko, S. A. (2015). Special features of individual learning systems from the worldview perspective. Advanced Education, 4, 27-31. Retrieved November 11 2017, from Advanced Education website, http://ae.fl.kpi.ua/article/view/56775

Kubacheva, K. I., Baeva, T. A. (2017) Teaching foreign language students sociotypes' (extroverts and introverts) personal characteristicsin non-linguistic faculties. Journal of Teaching English for Specific and Academic Purposes, 5 (2), 317-320. Retrieved November 11 2017, from JTESAP website, http://espeap.junis.ni.ac.rs/index.php/ espeap/article/view/525/316

Nikolic, V., Cabaj, H. (2000). Am I Teaching Well. Self-evaluation Strategies for Effective Teachers. Toronto: Pipin Publishing Corporation.

Oxford, R. L. (1990). Language Learning Strategies. What Every Teacher should Know. Boston: Heinle\&Heinle.

Reid, J. M. (1995). Learning Styles in the ESL/EFL Classroom. Boston: Heinle\&Heinle.

Bulygina, A. I. (1999). Psihologicheskie aspekty vzaimodejstvija "prepodavatel' student" pri individual'no-differencirovannom podhode v obuchenii [Psychological aspects of the "teacher-student" interaction with an individual-differentiated approach to teaching]. Unpublished candidate dissertation. Kazan', Russia.

Kitajgorodskaja, G. A. (1986). Metodika intensivnogo obuchenija inostrannym jazykam. Teorija i praktika [Methods of intensive teaching in foreign languages. Theory and practice]. Moscow: Vyssha shkola.

Klimchuk, V A. (2006). Trening vnutrennej motivacii [Internal motivation training]. SPb.: Rech'.

Kruteckij, V A. (1986). Psihologija [Psychology]. Moscow: Prosveshhenie.

Leont'ev, A. A. (2007). Jazyk, rech', rechevaja dejatel'nost' [Language, speech, speaking activity]. Moscow: KomKniga.

Muntyan, S. G. (2013) Indyvidualizatsiya navchannya inozemnoyi movy profesiynoho spryamuvannya $\mathrm{v}$ umovakh profil'noho VNZ [Individualization of teaching foreign language for specific purposes in the university-level professional education]. Narodna osvita, 2(20). Retrieved November 1 2017, from Narodna Osvita website, https://www.narodnaosvita.kiev.ua/?page_id=615

Zimovina, O. A. (2001). Individualizacija obuchenija $v$ vuze s uchetom dominirujushhih kognitivnyh stilej studentov [Individualization of education at the university with regard to the dominant cognitive styles of students]. Unpublished doctor dissertation. Sochi, Russia. 